\title{
E-ZAKAT: AN APPROACH FOR ZAKAT MANAGEMENT TO ERADICATE POVERTY
}

\author{
Md. Abdur Rouf \\ Department of Computer Science \& Engineering \\ Dhaka University of Engineering and Technology, Gazipur, Bangladesh \\ E-mail: abdurrouf.cse.duet@gmail.com \\ (D)https://orcid.org/0000-0003-4355-142X \\ Jahid Hasan Rony \\ Department of Computer Science \& Engineering \\ Dhaka University of Engineering and Technology, Gazipur, Bangladesh \\ E-mail:174067@ student.duet.ac.bd \\ Dhttps://orcid.org/0000-0002-6492-745X \\ Nazmul Karim \\ Department of Computer Science \& Engineering \\ Dhaka University of Engineering and Technology, Gazipur, Bangladesh \\ E-mail: nk.duet@gmail.com \\ (iDhttps://orcid.org/0000-0002-4985-2541 \\ Md Fahim Bhuyan \\ BSc Honor's in Computer Science \\ National University, Bangladesh \\ E-mail: fahim.ortb@gmail.com \\ https://orcid.org/0000-0001-6319-1789

\section{Dr. Momotaz Begum \\ Professor} \\ Department of Computer Science \& Engineering, \\ Dhaka University of Engineering and Technology, Gazipur, Bangladesh \\ E-mail: drmomotaz@duet.ac.bd \\ (D)https://orcid.org/0000-0002-1839-4963
}

Received: September 22, 2021 Accepted: November 30, 2021 Online Published: December 31, 2021

DOI: $10.46281 /$ ijibfr.v8i1.1521

URL: https://doi.org/10.46281/ijibfr.v8i1.1521

\begin{abstract}
This paper has shown an online-based zakat management system named E-ZAKAT. Zakat is one of the main foundational goals of the world's second-largest religion, Islam. So, it has indisputable importance for a country as well as the world economy and poverty eradication. During the COVID-19 pandemic, people have become habituated with the online system due to unavoidable
\end{abstract}


situations, such as education and commodity market has now turned into online systems. However, an online base zakat management system for both donors and seekers has not prevailed widely. Here in this proposed system, the donor can calculate, donate their zakat, and the seeker can apply to receive it. Instead of providing cash, business or agricultural help is planned to ensure the economic stability of a low-income family. For this purpose, the expectant can claim support for green farming, agricultural equipment, or money to start a small business after ensuring the required verification and qualification steps. The proposed dynamic web application E-ZAKAT will provide an easier and hassle-free system for zakat donors and seekers with an attractive design. As a result, proper utilization of our system could provide a positive impact to change our society as well as our world.

Keywords: E-ZAKAT, Zakat Donor, Zakat Seeker, Online System.

JEL Classification Codes: I3, N3, P36, P46, H3.

\section{INTRODUCTION}

Zakat ranks after prayer, which plays a very significant role in financial management for Muslims and is also mandatory for those who meet the required criteria of wealth. The major advantage of Zakat is that it purifies money and wealth. The general minimum sum for qualifiers is $2.5 \%$ or $1 / 40$ of the total reserve fund and assets of Muslims (Suhaib, 2009). If personal wealth is below the nisab within one lunar year (referring to the minimum amount of wealth and a Muslim has to demand some time to pay Zakat recently), then no zakat has to be paid for that time.

Zakat donors are the adults who have reached puberty, Muslims (non-Muslims do not pay Zakat), fully owned by Nisab (minimum criteria of wealth). In addition, the categories of assets that are imposed on Zakat are cash capital, property, precious metals, business assets and stocks. On the other hand, there are eight types of people who can receive Zakat, the poor (low-income or indigent), the needy (the person who is in trouble), zakat collector, people who have converted to Islam and are in need, people who are bound (slaves and captives), people who are in debt, those who fight for the propagation of Islam and those who are trapped because of having few resources to travel (Anis \& Kassim, 2016).

Despite having such important people are not fully concerned about Zakat because of proper Islamic knowledge, lack of information about the management, and calculation procedure. Because of inexperience, people donate some money and goods or clothes to the poor without calculation only based on conjecture and think that they have fulfilled their duty of Zakat. However, the assumption is not the correct way for paying Zakat by the rules of Islam. To correctly fulfil the Zakat, a person has to precisely calculate the payable amount and also donate to the rightful person. On the other hand, lots of poor people feel shy to ask for the Zakat publicly though they meet the requirement to receive Zakat. However, if they could apply for Zakat via an online system, it would be helpful for both the donor and seeker. The social impact that Zakat can have is also unaware in our society because there is no central management and distribution system to coordinate properly. Random donations to random people could not make such noticeable financial changes in the long term. However, the proper central coordination could have a great impact on economic GDP growth. For example, helping in raising cattle, helping in agricultural work/equipment, helping to establish small businesses, buying rickshaws or helping to buy sewing machines for certain people would change their fate rather than donating small amounts of money every year.

The main focus of our paper is to provide a fully online based Zakat management system, 
'E-ZAKAT', which provides accurate knowledge about the process of Zakat, calculation procedure, and system to donate as well as seek/receive Zakat.

Contribution of this paper:

- Fully online based system 'E-ZAKAT'

- Provide the fundamental knowledge about Zakat

- Online application process for both the donor and seeker

- User friendly calculation procedure

- Ensure proper distribution of Zakat

The rest of the paper is organized as follows. Section 2 represents the previous studies, then prosed methodology and its description are in Section 3 where subsection 3.1 shows the methodology of the system and system description is in subsection 3.2. In Section 4, the result and performance description of the system are evaluated from different perspectives. The paper concludes with future plans in Section 5.

\section{LITERATURE REVIEW}

Zakat is one of the five main foundational goals of Islam. All eligible Muslims have to give $2.5 \%$ of their accumulated wealth to the poor and needy people. A 1.8 billion people's community (Kettani, 2010) has an extensive impact on the world economy; as a result, several studies and approaches have been proposed earlier in this field. The importance of Zakat has been highlighted in different papers like (Hamidi et al., 2019; Malik, 2016; .The Impact of Zakat on Social Life of Muslim Society - IRI - Islamic Research Index - Allama Iqbal Open University, Islamabad, n.d.). Isahaque Ali presented a paper about using the zakat fund for poverty reduction as an alternative to the microcredit system in the perspective of Bangladesh (Ali, 2019). Besides that, Uddin et al. (2020) showed similar studies showing promising results that Zakat programs help increase average monthly income, assets and establish substantial livelihood.

In (Ali \& Hatta, 2011), a study has shown the impact of Zakat from the perspective of social work. This paper also has shown that Zakat has a great positive impact on our society to eradicate poverty effectively. Studies have been done to determine the potentiality and scope of Zakat in different countries. Impact of Zakat funds in Bangkok, Thailand has been studied in (Sitisan, 2010), another Muslim country, Pakistan has been published by Suhaib (2009) with aspects of different potentiality and scope. After that, Anis and Kassim (2016) presented the outcome of the Zakat based poor woman empowerment effort by the Center for Zakat Management $(\mathrm{CZM})$ in the Chittagong district of Bangladesh. Another related paper was published about the impact of Zakat for community development in kendal, Sukorejo district, Indonesia (Rahmat \& Nurzaman, 2019).

After reviewing the mentioned papers, it is needless to expound on the importance and impact of the social betterment of Zakat in society. So, different zakat management systems have been proposed in the last few decades. For example, Ulya (2018) discussed the legal protection of Zakat based on donations from both positive and Islamic laws on modern financial technology. In addition, Andiani et al. (2018) present two zakat collection and management strategies of Indonesia. In (Muhammad, 2019) Izlawanie Muhammad analyzed the zakat management system of seven richest muslim countries and in spite of having modern technology among them only two country Oman and United Arab Emirates accepts online zakat applications and have available transparency data not fully online system.

Because of the limited knowledge about Zakat and proper utilization of modern technology, still, now people have to use hand to hand transactions where the seeker physically 
comes and asks for Zakat from the donor (Ahmad et al., 2015). Lubis et al. (2019) have shown a comparison study about different zakat management approaches. In addition, a masjid-based management system was proposed by Kausar et al. (2016). Consequently, (Ninglasari \& Muhammad, n.d.) explained how the zakat management system adopted digitalization and analyzed the role during the Covid-19 pandemic. From the aforementioned studies, it is obvious that an online base proper zakat management system is still necessary for this vital Islamic process for poverty eradication. So, the objective of our paper is to provide a fully digitalized online Zakat management system noted, 'E-ZAKAT'

\section{Methodology}

\section{SYSTEM ARCHITECTURE}

Provide the overall system architecture of 'E-ZAKAT' is described in figure 1. At first, we are collecting both Zakat and seeker applications from different sources via online. The second step is coordinating between Zakat donors and seekers by the central Zakat management authority. Central management has two parts. One is the Zakat donor section, where the donors will learn the fundamental knowledge of Zakat with different Islamic references, and calculate the amount of his/her Zakat and finally pay the Zakat through an online payment. On the other hand, Zakat seeker will connect to the eligibility checking and verification procedure according to the criteria of Zakat in Islam. The Zakat Management Authority will periodically review the information of those who have applied for Zakat and verify and select how they can assist one of them or whether he is eligible to receive Zakat. In the case of candidates applying for Zakat, several factors are considered, such as their ability, family members, and the number of family members who can earn. If the Zakat seeker passes the eligibility process, he/she will have to wait for the financial aid for supporting or establishing a small project; otherwise, they will be terminated from the system. The main motivation of the 'E-ZAKAT' system is to help the Zakat seeker to be financially well off permanently by establishing small projects instead of giving cash such as buying vehicles for transportation, green farming equipment for starting farming or money for opening a shop. Hence, they do not have to look to others for help, and they can be career, livelihood oriented and selfemployed. As a result, the economic condition of the society will improve significantly.

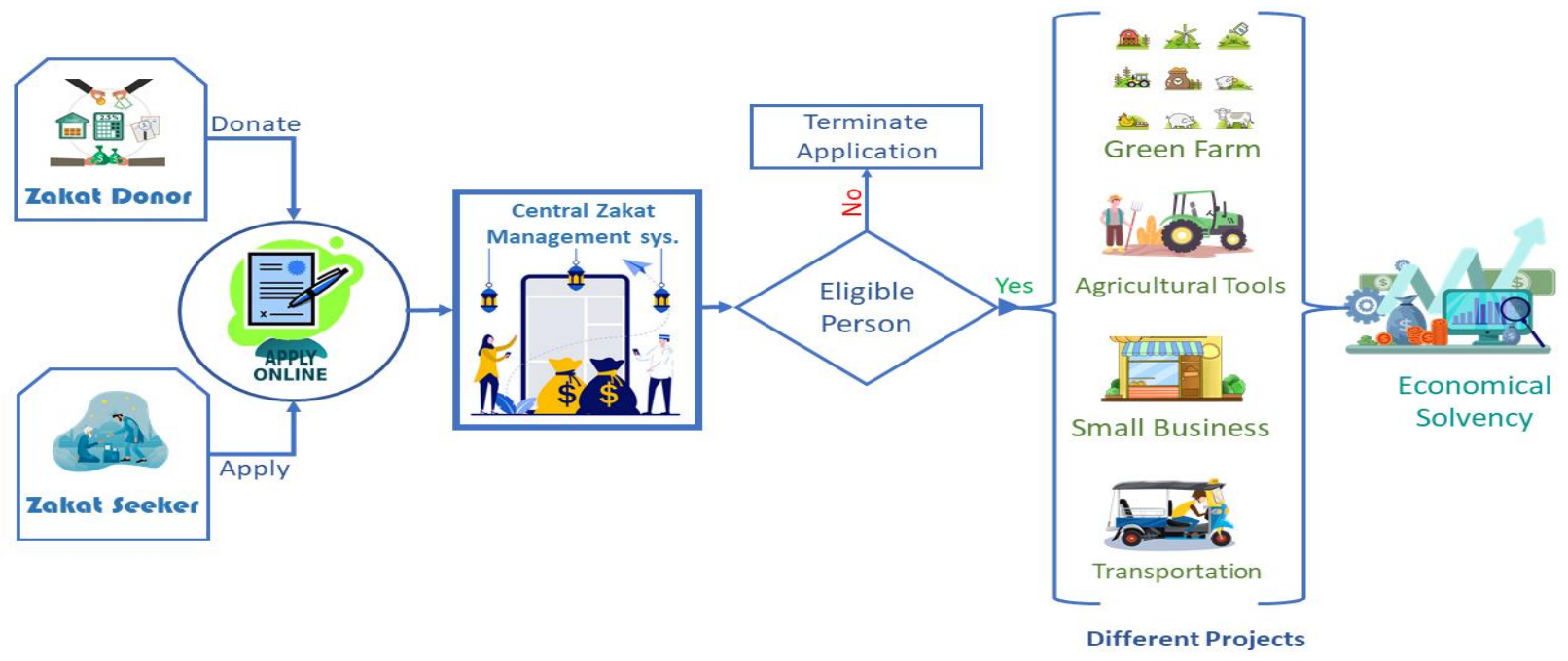

Figure 1. System Architecture of 'E-ZAKAT' 
Analysis of data and the reporting of the results of those analyses are fundamental aspects of the conduct of research. Accurate, unbiased, complete, and insightful reporting of the analytic treatment of data (be it quantitative or qualitative) must be a component of all research reports. Researchers in the field of psychology use numerous approaches to the analysis of data, and no one approach is uniformly preferred as long as the method is appropriate to the research questions being asked and the nature of the data collected. The methods used must support their analytic burdens, including robustness to violations of the assumptions that underlie them, and they must provide clear, unequivocal insights into the data.

\section{System Description}

The 'E-ZAKAT' System is an online-based web application designed to eradicate poverty through user-friendly and proper Zakat distribution. We have divided the functions of our system into three main parts: 'E-ZAKAT' donor, 'E-ZAKAT' seeker, 'E-ZAKAT' authority.

\section{'E-ZAKAT' Donor}

Different functionalities of 'E-ZAKAT' donors are shown in figure 2. For the first time, the Donor has to register using 'E-Zakat' by providing some basic information such as name, address, password etc. Then the user can log in to the system by providing the email and password represented in Figure 2 (a).

'E-ZAKAT' is a user-friendly system where users can modify and update their profile after login. For example, they can upload their photo, national identification number (NID), phone number, etc. That information helps to identify the donors in the system for future usage as well as, he/she will be a registered member of the system presented in Figure 2 (b).
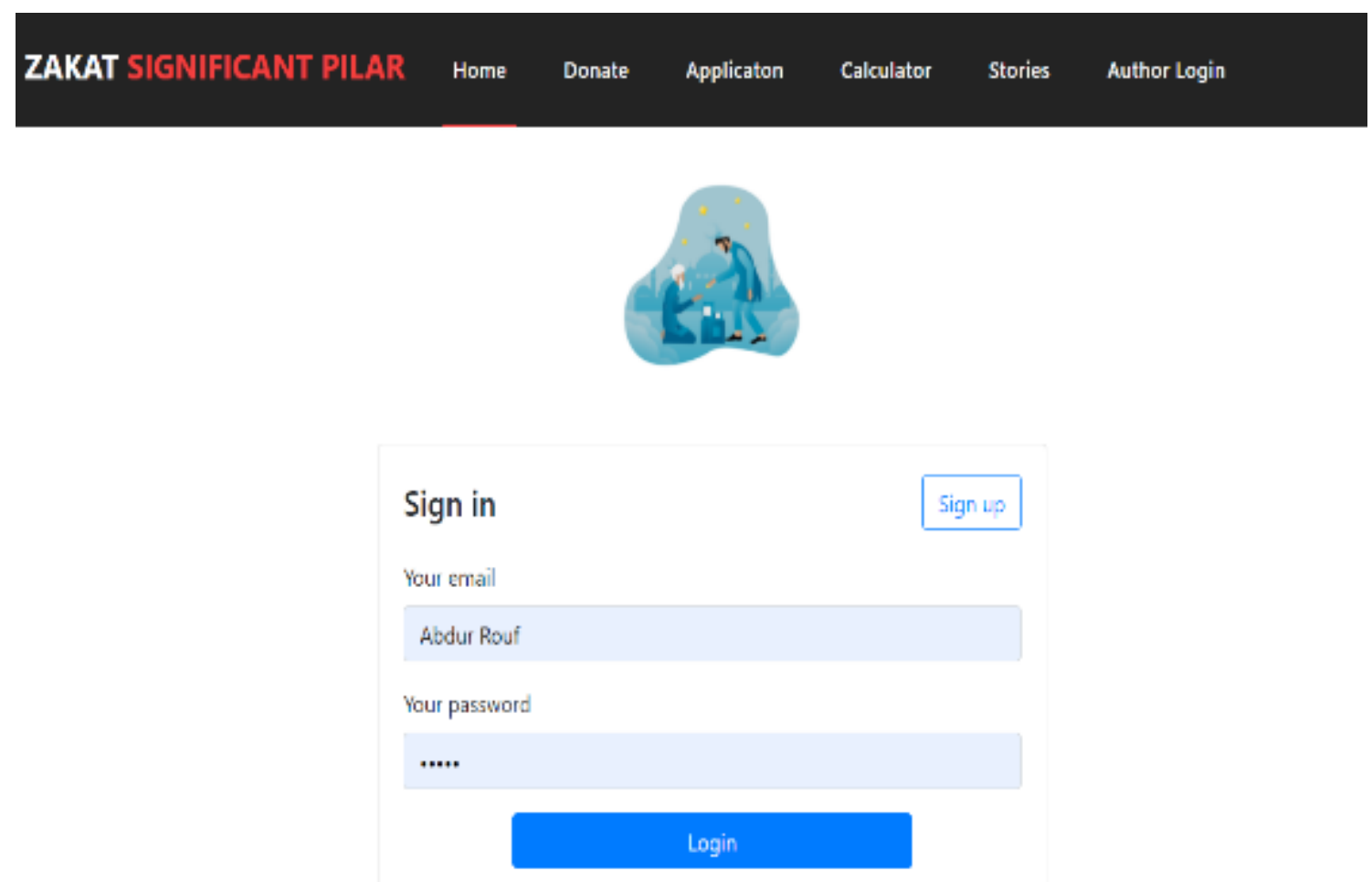

(a) Login system 


\section{ZAKAT SIGNIFICANT PILAR Home Donate Applicaton Calculator Stories Author Login}

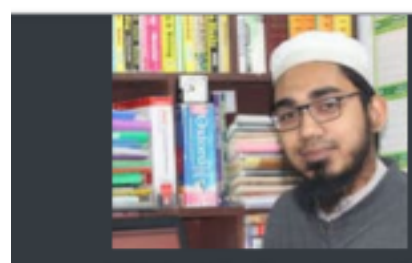

MD. Abdur Rouf

Home

Work

Edit

View Donation

Sign Out

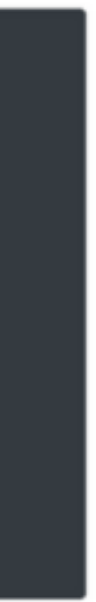

\section{User Profile}

Full Name:

Email:

Phone Number:

Address:

NID:
MD. Abdur Rouf

abdurrouf.cse.duet@gmail.com

1846090606

DUET, Gazipur

2147483647

(b) User Profile

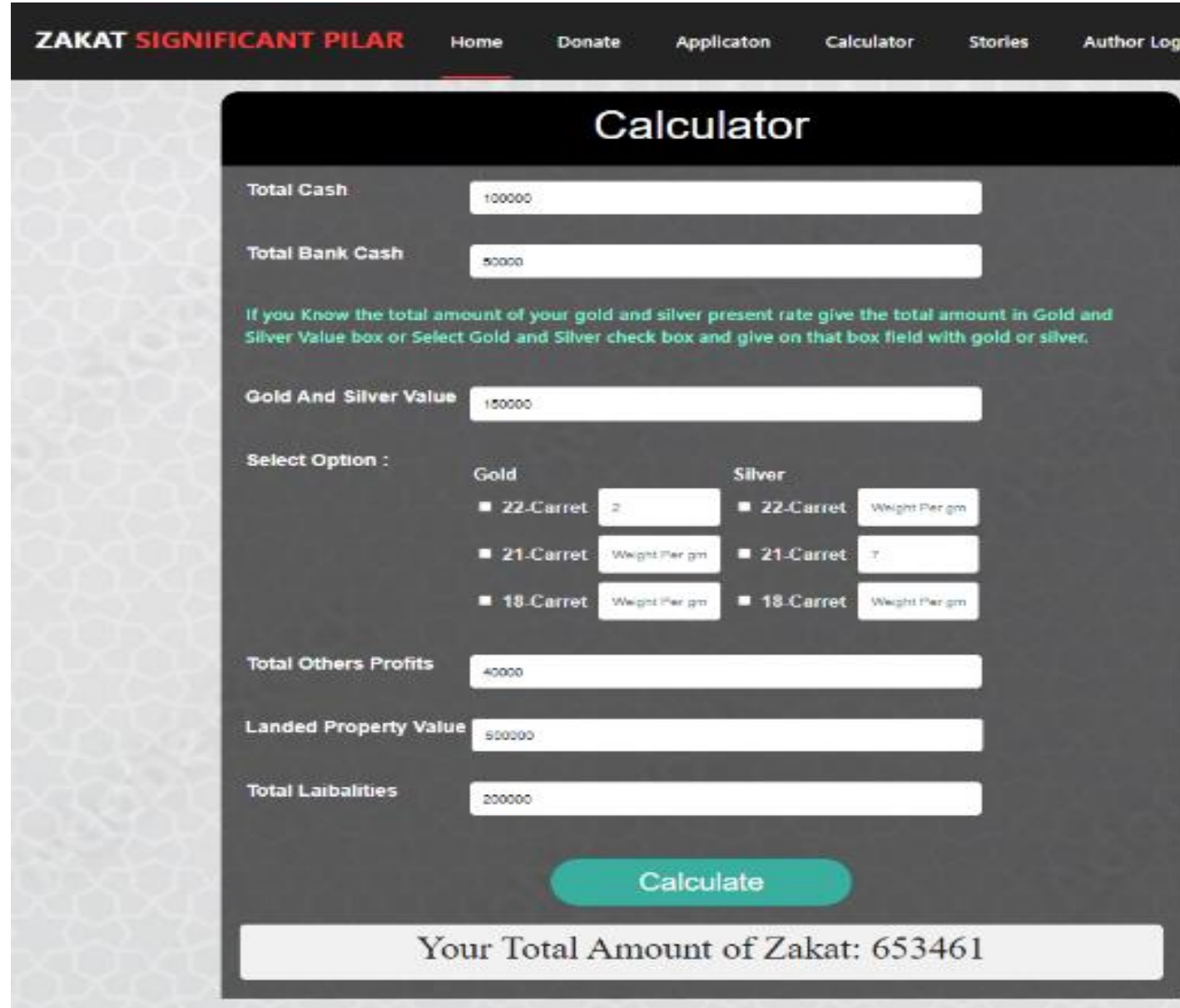

(c) Calculator 


\section{ZAKAT SIGNIFICANT PILAR Home Donate Applicaton Calculator Stories Author Login}

\section{Donation Form}

welcome

MD. Abdur Rouf

Go to Profile

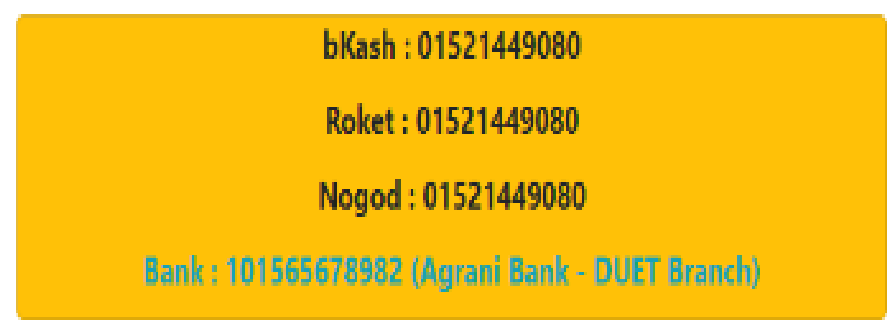

\begin{tabular}{|c|c|c|}
\hline Donate Amount & \multicolumn{2}{|c|}{ Payment Method: } \\
\hline 50000 & bKash & 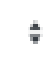 \\
\hline Transaction ID / AcC & \multicolumn{2}{|l|}{ Date: } \\
\hline 54876114532 & $07 / 14 / 2021$ & 曰 \\
\hline \multicolumn{3}{|l|}{ Choice field (Optional) } \\
\hline Medical treatment & & 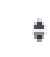 \\
\hline
\end{tabular}

(d) Online payment sys

Figure 2. 'E-ZAKAT' Donor's Functionalities 


\section{'E-ZAKAT'Seeker}

ZAKAT SIGNIFICANT PILAR Home Donate Applicaton Calculator Stories Author Login

\section{Application Form for getting Zakat}

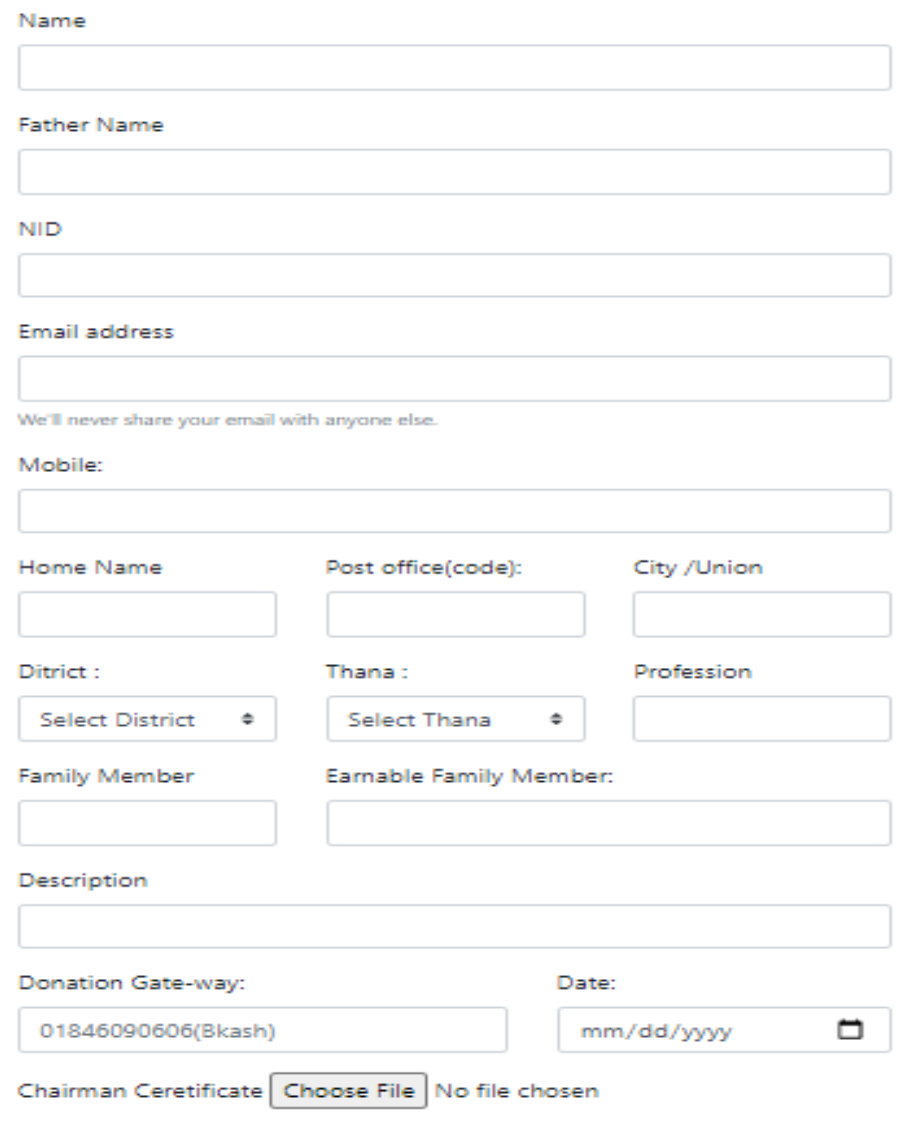

Submit

Figure 3. 'E-ZAKAT' Seeker's Functionality

In Figure 3, Zakat seeker's registration form is shown where the applicant needs to input their name, NID number, mobile number, address, family member information, family's financial condition, certificates from the local administrators and some other information that will be used for the verification process. After registration and application, applicants have to wait for the verification process. Once the verification is completed, any further updates will be available in their profile.

\section{'E-ZAKAT' Authority}

Coordination between Zakat donor and seeker is the main duty of the authorization system. Verifying and confirming the donation, Zakat seeker application verification and 'E-ZAKAT' 
project distribution among eligible Zakat seekers is done by the 'E-ZAKAT' Authority. The authorization committee manually approves the Zakat seeker application after a solid authentication and consideration as well as they also analyze and assign the available projects to the applicants. If an application fails to meet the eligibility criteria, 'E-ZAKAT' authorities reject the application and notify the applicant.

\section{RESULT AND DISCUSSION}

Recent studies have shown that for the economic growth in Bangladesh, Zakat can play a vital role. The estimated amount of the Zakat economy in Bangladesh is approximately BDT Thirty Thousand (30000) crore. Even so, the Bangladesh government Zakat management system collects and distributes a small percentage of the total Zakat. In the recent financial year 2019-2020, five crore eighteen lakh taka was collected by the government zakat fund (Zakat Economy, 2021), which shows the poor condition of the Zakat management system. Due to the lack of an available online base system, proper knowledge and sincereness of Zakat, most people pay Zakat individually. Nevertheless, the individual Zakat donation cannot ensure proper distribution and coordination. As a result, it is not possible to achieve the main objective of Zakat, which is to eradicate poverty permanently and provide employment to the poor. However, this is possible only when we can motivate everyone to pay Zakat in a well-organized manner.

To our best knowledge, 'E-ZAKAT' would be the first complete online base solution for Zakat management in Bangladesh. Suppose we could implement our proposed system in Bangladesh; we hope that the system will be able to collect Zakat of approximately BDT one hundred twenty (120) crore by 2022 through 'E-ZAKAT'. After that, the Zakat authority will distribute money to verify 'E-ZAKAT' seekers for individuals' businesses such as fruit, forest, fisheries, transportation, or livestock farms at the cost of BDT fifty thousand $(50,000)$ from the total amount of Zakat collection of that fiscal year. In such way, around twenty thousand $(24,000)$ families will get a chance to change their fate by utilizing this opportunity and hopefully, by the next year, they will not have to apply for Zakat again. From the past year feedback, 'E-ZAKAT' will be able to help more and more people every year. For a clear view, if the 'E-ZAKAT' authority can help 24000 families per year, within the next 10 years, more than 240000 families will get the benefit and probably eradicate poverty shown in figure 4

Projects will make a large amount of employment year by year

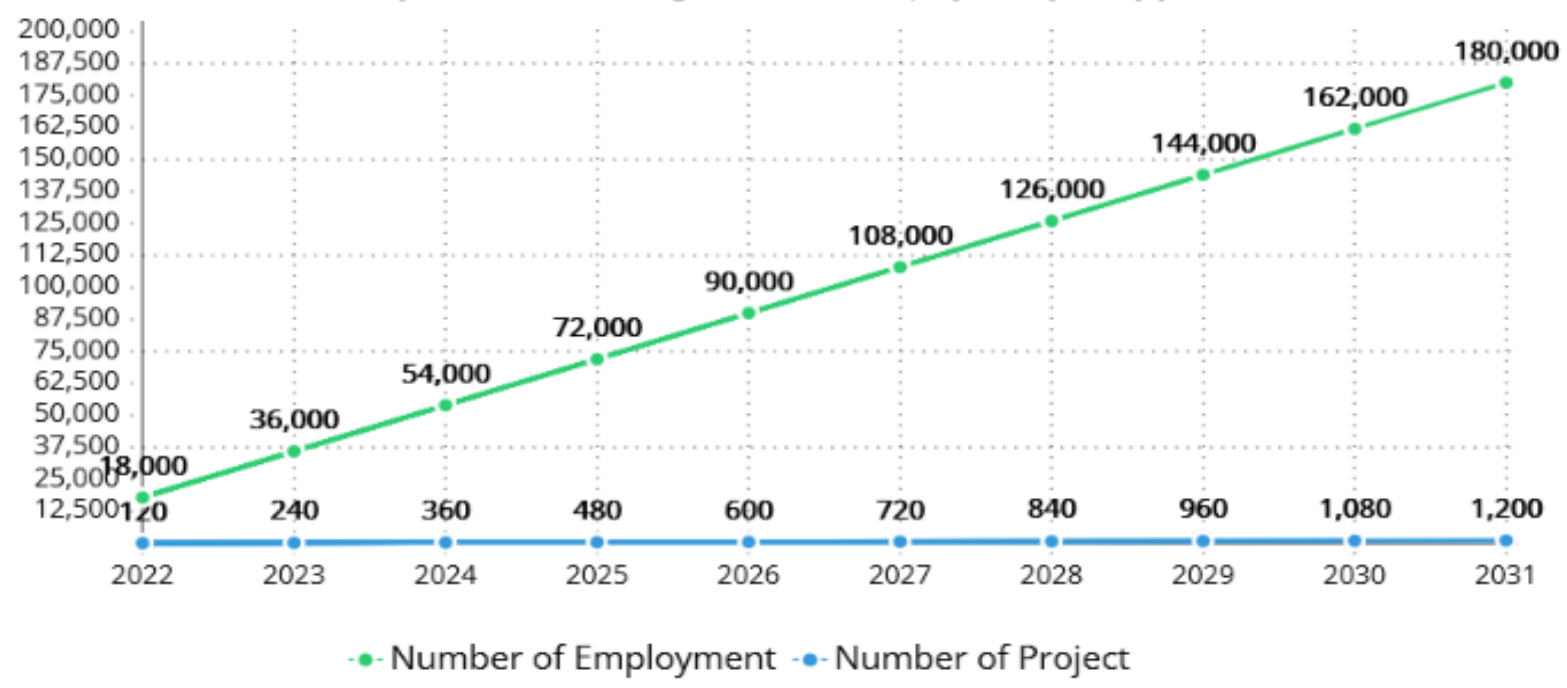

Figure 4. Relation between number of Employment and Yearly in 'E-Zakat'. 


\section{CONCLUSION}

Zakat is one of the five most important pillars of Islam, which can play a huge role in eliminating the financial inequality of the society. However, in order to make it effective and fruitful, proper and transparent economic pre-planned management of Zakat is required. We hope to create a better and more effective zakat management model through the 'E-ZAKAT' management project that we are trying to implement. This paper has proposed an easily accessible, user-friendly online-based Zakat management system - 'E-ZAKAT' in terms of Bangladesh. Using our system, Zakat donors and seeker can donate and receive Zakat with transparency and security. In addition, women and disabled people also apply for Zakat easily. The maintenance cost of this proposed system is very low. Throughout a comprehensive analysis of our system with approximation without doubt, we can say 'E-ZAKAT' plays an effective and successful role in developing Muslim society's social life and moral values. In the future, we will bring the system into mobile apps to improve easy accessibility. The 'e-Zakat' management system will work to ensure that all classes of people become aware of Zakat and emerge with proper management of Zakat. This will reduce the suffering in the life of zakat recipients and donors will be relieved.

\section{AUTHOR CONTRIBUTIONS}

Conceptualization: Md. Abdur Rouf, Nazmul Karim, Momotaz Begum

Data Curation: Momotaz Begum, Jahid Hasan Rony, Md. Abdur Rouf

Formal Analysis: Md. Abdur Rouf, Nazmul Karim, Md Fahim Bhuyan, Momotaz Begum, Jahid Hasan Rony

Funding Acquisition: Momotaz Begum, Md Fahim Bhuyan

Investigation: Md. Abdur Rouf, Nazmul Karim, Momotaz Begum

Methodology: Md. Abdur Rouf, Nazmul Karim, Momotaz Begum

Project Administration: Momotaz Begum

Resources: Md. Abdur Rouf, Nazmul Karim, Momotaz Begum

Software: Md. Abdur Rouf, Nazmul Karim

Supervision: Momotaz Begum

Validation: Md. Abdur Rouf, Nazmul Karim, Md Fahim Bhuyan, Momotaz Begum

Visualization: Md. Abdur Rouf, Nazmul Karim, Md Fahim Bhuyan, Momotaz Begum

Writing - Original Draft: Jahid Hasan Rony, Md. Abdur Rouf

Writing - Review \& Editing: Momotaz Begum, Jahid Hasan Rony, Md. Abdur Rouf

\section{CONFLICT OF INTEREST STATEMENT}

The authors declare that they have no competing interests.

\section{ACKNOWLEDGEMENT}

All authors contributed equally to the conception and design of the study.

\section{REFERENCES}

Ahmad, R. A. R., Othman, A. M. A., \& Salleh, M. S. (2015). Assessing the Satisfaction Level of Zakat Recipients Towards Zakat Management. Procedia Economics and Finance, 31, 140-151. https://doi.org/10.1016/S2212-5671(15)01141-7

Ali, I. (2019). Zakat as an Alternative of Microcredit for Poverty Reduction in Bangladesh. Undefined. Retrieved from https://www.semanticscholar.org/paper/Zakat-as-anAlternative-of-Microcredit-for-Poverty- 


\section{Ali/e33a3c632781abdd04cb2e7bbd22855e37044f68}

Ali, I., \& Hatta, Z. A. (2011). The role of Zakat in poverty reduction in Bangladesh from a community social work perspective. International Journal of Business and Technopreneurship, 1(3), 467-478.

Andiani, K., Hafidhuddin, D., Beik, I. S., \& Ali, K. M. (2018). Strategy of BAZNAS and Laku Pandai For Collecting and Distributing Zakah in Indonesia. Al-Iqtishad: Jurnal Ilmu Ekonomi Syariah, 10(2), 417-440.

Anis, F. M., \& Kassim, S. H. (2016). Effectiveness of zakat-based programs on poverty alleviation and economic empowerment of poor women: a case study of Bangladesh. Journal of Islamic Monetary Economics and Finance, 1(2), 229-258.

Hamidi, I., Suhel, S., \& Latif, A. (2019). The effectivities of zakat productive funds toward zakat recipient income in Palembang. Jurnal Ekonomi Pembangunan, 17(1), 24-30. https://doi.org/10.29259/jep.v17i1.8965

Kausar, A., Alauddin, M., \& Kabir, M. (2016). A Masjid Based Zakat Management Model in Alleviating Poverty: Bangladesh Perspective. International Journal of Ethics in Social Sciences, 4(2), 63-82.

Kettani, H. (2010). Muslim Population in Asia: 1950 - 2020. International Journal of Environmental Science and Development, 1(2), 143-153. https://doi.org/10.7763/IJESD.2010.V1.28

Lubis, M., Ridho Lubis, A., \& Almaarif, A. (2019). Comparison of the Approach in the Zakat Management System. 1235, 012048. https://doi.org/10.1088/1742-6596/1235/1/012048

Malik, B. A. (2016). Philanthropy in Practice: Role of Zakat in the Realization of Justice and Economic Growth. International Journal of Zakat, 1(1), 64-77. https://doi.org/10.37706/ijaz.v1i1.7

Muhammad, I. (2019). Analysis of Zakat System in High-Income Islamic Countries. The Journal of Muamalat and Islamic Finance Research, 16(2), 1-11. https://doi.org/10.33102/jmifr.v16i2.219

Ninglasari, Y., \& Muhammad, M. (n.d.). Zakat Digitalization: Effectiveness of Zakat Management During Covid-19 Pandemic. Retrieved from https://www.semanticscholar.org/paper/Zakat-Digitalization\%3A-Effectiveness-ofZakat-During-Ninglasari-Muhammad/56a6c5f7bebd26b5e6cc6d778eae742a46e442b8

Rahmat, R. S., \& Nurzaman, M. S. (2019). Assesment of zakat distribution: A case study on zakat community development in Bringinsari village, Sukorejo district, Kendal. International Journal of Islamic and Middle Eastern Finance and Management, 12(5), 743-766. https://doi.org/10.1108/IMEFM-12-2018-0412

Sitisan, E. S. (2010). Perception on Potential of Zakat Fund In Muslim Society In Bangkok, Thailand. Retrieved from http://eprints.usm.my/42470/1/EKARAT_SITISAN_HJ.pdf

Suhaib, A. Q. (2009). Contribution of Zakat in the Social Development of Pakistan. Pakistan Journal of Social Sciences, 29(2), 313-334. 
The Impact of Zakat on Social life of Muslim Society - IRI - Islamic Research Index - Allama Iqbal Open University, Islamabad. (n.d.). Retrieved from https://iri.aiou.edu.pk/indexing/?p=3775

Uddin, M. N., Hamdan, H., Che Embi, N. A., Kassim, S., \& Md Saad, N. (2020). The effect of zakat programs on the social impact of microfinance institutions in Bangladesh. International Journal of Zakat and Islamic Philanthropy, 2(1), 165-174.

Ulya, N. U. (2018). Legal Protection of Donation-based Crowdfunding Zakat on Financial Technology: Digitalization of Zakat under Perspective of Positive Law and Islamic Law. International Conference of Zakat. https://doi.org/10.37706/iconz.2018.132

Zakat economy: Little use of a huge potential. (2021, April 22). The Business Standard. Retrieved from https://www.tbsnews.net/feature/tbs-ramadan/zakat-economy-little-use-hugepotential-235597

\section{Copyrights}

Copyright for this article is retained by the author(s), with first publication rights granted to the journal. This is an open-access article distributed under the terms and conditions of the Creative Commons Attribution license (https://creativecommons.org/licenses/by/4.0). 